\title{
Powdery mildew damage to the production of BRS 189 cashew plants $^{1}$
}

\author{
Joilson Silva Lima², Marlon Vagner Valentim Martins ${ }^{3 *}$ (D), José Emilson Cardoso ${ }^{3}$ \\ 10.1590/0034-737X201966020008
}

\begin{abstract}
Powdery mildew, caused by the fungus Pseudoidium anacardii, is currently the most important cashew disease, affecting leaves, inflorescences, and fruits. However, there is a lack of detailed reports associating the effects of $P$. anacardii to cashew yield. Therefore, the objective of this study was to determine the damage caused by powdery mildew to BRS 189 cashew clone nut, kernel, and peduncles. One experiment was conducted at the Embrapa Agroindústria Tropical Experimental Field in Pacajus, state of Ceará, Brazil, from July to December 2014, with BRS 189 cashew clone, with eight sulfur doses needed for achieving a disease gradient, distributed in a randomized block with four replications. The incidence (\%) and severity of powdery mildew in cashew plants were estimated in a scale ranging from 0 to 4 , and then correlated with plant yield and biometric characteristics of cashew nuts, kernels, and peduncles. The results showed that powdery mildew did not reduce productivity of nuts on this clone, although it caused a reduction in the mass and size of the kernels. On the other hand, powdery mildew affected mass, size, and quality of cashew peduncles at the lack of control.
\end{abstract}

Keywords: Anacardium occidentale; incidence; Pseudoidium anacardii; severity.

\section{INTRODUCTION}

Cashew nut (Anacardium occidentale L.) is the primary product exploited in Brazil and in the international market. However, it shows a great potential for value aggregation when the peduncle is better utilized (Souza et al., 2004), particularly in juice production (Costa et al., 1999) and in the table market, consumed as a fresh fruit.

As improved dwarf cashew nuts (Oliveira et al., 2003) were introduced, which represented a great technological advance for the exploitation of this crop, significant yields for the nuts and peduncle were achieved (Cavalcanti et al., 2000; Serrano et al., 2013a). However, despite being considered a rustic plant and well adapted to the conditions of the Brazilian Northeast, significant damages have been observed in the field with loss in quantitative and qualitative terms caused mainly by fungi during the cashew growth cycle (Freire et al., 2002; Cardoso et al., 2013).
The cashew powdery mildew, caused by fungus Pseudoidium anacardii (F. Noack) U. Braun \& R.T.A. Cook, is considered a secondary disease for decades in Brazil, with no damages on the production of nuts and peduncle (Freire et al., 2002); it has been responsible for significant damages on cashew trees in Brazil (Cardoso et al., 2012), a fact that has been observed in African countries (Casulli, 1979; Martin et al., 1997; Sijaona et al., 2001). In Africa, particularly in Tanzania, production has declined from 50 to $70 \%$ due to the attack of powdery mildew (Martin et al., 1997). Nowadays, powdery mildew is the major disease associated to cashew in Brazil, where severe attacks have been observed on leaves, inflorescences, maturis, and mature cashew, damaging the quality of the nut (Serrano et al., 2013b; Pinto et al., 2016) and the peduncle intended for the market.

In general, powdery mildew is responsible for attacking more than 1500 plant genera (Braun \& Cook, 2012), causing

\footnotetext{
Submitted on Octuber $24^{\text {th }}, 2018$ and accepted on March $08^{\text {th }}, 2019$.

${ }^{1}$ This paper is part of Doctoral Thesis of the first author.

${ }^{2}$ Instituto Federal de Educação, Ciência e Tecnologia do Ceará - Eixo Tecnológico de Recursos Naturais, Sobral, Ceará, Brazil. joilson.lima@ifce.edu.br

${ }^{3}$ Embrapa Agroindústria Tropical, Laboratório de Fitopatologia, Fortaleza, Ceará, Brazil. marlon.valentim@embrapa.br; jose-emilson.cardoso@embrapa.br

*Corresponding author: marlon.valentim@embrapa.br
} 
significant damage to production in several hosts (Bowen et al., 1991; Reis et al., 2002; Godoy \& Canteri, 2004; Santos et al., 2005; Barros et al., 2006; Camele et al., 2009; Igarashi et al., 2010; Wang et al., 2014; Watson, 2016), most of them, cereal. Regarding fruticulture, studies on damage to the plant production are scarce (Santos et al., 2005; Martins et al., 2014), and none of them reports the damages that powdery mildew may cause to cashew yield.

In studies carried out in the African continent, where cashew nut production is a major agricultural activity, no study on damages has been carried out when the disease is associated with the production of the plant. Most of the studies carried out refer to the chemical control (Smith et al., 1995; Smith et al., 1997; Smith \& Cooper, 1997; Sijaona \& Mansfield, 2001), epidemiological studies of the disease (Shomari \& Kennedy, 1997, 1999), and genetic improvement (Sijaona \& Mansfield, 1997). Despite the estimated fall of 50 to $70 \%$ in cashew nut production in Tanzania (Martin et al., 1997), no mention is made of production damage in cashew nuts affected by powdery mildew. Topper et al. (1997a; 1997b) reported a decline in cashew nut production in Tanzania when no control on powdery mildew was carried out, but without estimating the damage that the disease may cause to the cashew tree.

No studies quantifying the damages to the production of the nut, kernel, or peduncle when the dwarf cashew is attacked by $P$. anacardii during the productive cycle of the plant are found in the literature. Therefore, the objective of the present study was to determine the damage caused by powdery mildew to the production of cashew, kernels, and peduncle of BRS 189 dwarf cashew clone.

\section{MATERIALAND METHODS}

The experiment was conducted in the Experimental Field of Embrapa Agroindústria Tropical $\left(4^{\circ} 1^{1} 16^{\circ} \mathrm{S}, 38^{\circ} 29^{1} 50^{\circ} \mathrm{W}\right.$, $77 \mathrm{~m}$ ), located in Pacajus, Ceará - Brazil, from July to December, 2014 in an area of 0.8 ha cultivated with 168 plants of the dwarf cashew clone BRS 189 (highly susceptible to powdery mildew), implanted in 2001, with a spacing of $8 \times 6 \mathrm{~m}$, from seedlings grafted on clone CCP 06 .

In May 2014, two months prior to the start of the experiment, the plants were pruned. The soil of the place has predominance of Quartzarenic neosol with sand textural class. Fertilization, cultural treatments, and phytosanitary management were carried out according to the recommendations proposed by Embrapa Agroindústria Tropical (Oliveira, 2002). During the study period, accumulated rainfall was $39 \mathrm{~mm}$, with relative humidity and average temperature of $72.27 \%$ and 27.53 ${ }^{\circ} \mathrm{C}$, respectively.

For establishment of the disease gradient, increasing doses of sulfur (Kumulus ${ }^{\circledR} \mathrm{DF}$ ) ranging from 0 to $7 \mathrm{~g}$ of the product ( $80 \%$ a.i.) per liter of water $(1.25 \mathrm{~L}$ of fungicide volume/plant/ application) were applied. At first, the applications were carried out at weekly intervals, then fortnightly after the third spray. The volume was applied with $0.05 \%$ (Polyoxyethylene sorbitan monolaurate) as dispersing agent (spreader). Sulfur applications were performed with a motorized backpack sprayer, starting on July 30, ending on November 13, 2014, totaling nine sprayings.

The experiment, with eight treatments $(0,0.5,1,2,3,4$, -5 , and $7 \mathrm{~g}$ product/L of water), was conducted in a randomized block design with four replications, with two plants per plot. Panicles were marked on opposite sides of each plant (cardinal points), identified with colored tissue attached to a cotton string, and assessed for disease during the experimental period. The evaluation of the incidence and severity of powdery mildew was performed weekly in 1280 panicles and, before cashew harvesting, in 800 chestnuts and 200 peduncles/treatment.

Severity was estimated using a descriptive scale of scores ranging from 0 to 4 , adapted from Cardoso et al. (2012), estimated as a function of the percentage of the wounded area in the organs of the plant, in which 0 represented the absence of disease, 1 represented up to $10 \%$ of the organ surface affected, 2 represented between 11 and 25\%, 3 between 26 and 50\%, and 4 was written down when the injured area compromised more than $50 \%$ of the evaluated organ surface. The incidence was estimated by percentage (\%) of organs infected by the fungus [number of sick organs/total number of organs evaluated $* 100]$.

At the end of the cycle, the number of fruits/panicle was determined, as was the number and total mass of fruits produced/plant; mass, length, width, and average thickness of the nut; average epicarp mass (skin); average mass of the mesocarp (pellicle); mass, length, width, and average thickness of the kernel; and average mass, average length, average width, and total soluble solids (TSS) of the peduncle.

The damage estimate was obtained from the relationship between disease [severity on panicles (SevPan), nuts (SevCast), and peduncles (SevPseud); incidence on flowers (IncFlor) and fruits (IncFruto); and the area underneath the disease progress curve in flowers (AACPD)] and production (number of fruits/panicle; number of fruits/plant; total fruit mass/plant; mass, length, width, and thickness of nuts; epicarp mass; mesocarp mass; and mass, length, width, and thickness of kernels; and mass, length, width, and TSS of peduncles), obtained with linear regression analysis, using mean values of the entire productive cycle of the crop, except for number and mass of fruits/plant, which were represented by the sum of the values of the five flowerings. 
The AACPD (Campbell \& Madden, 1990) was calculated from the data on severity of powdery mildew in panicles (AACPSevPan) and the incidence of powdery mildew in flowers (AACPIncFlor) as a function of time. The data were submitted to analysis of variance, using the F test and linear regression analysis.
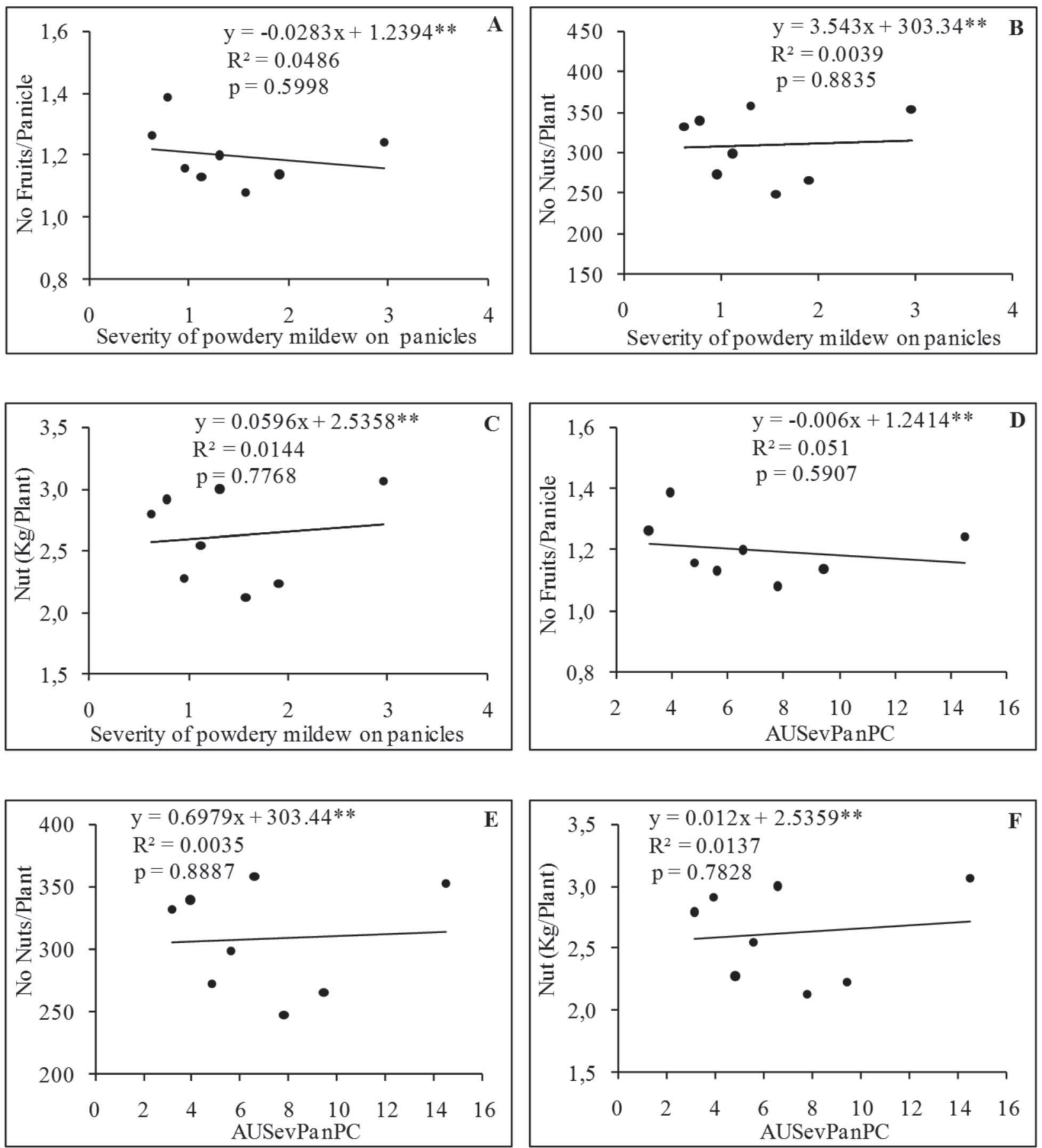

Figure 1: Relationship between the severity of powdery mildew on panicles (SevPan) of BRS 189 cashew plant and number of fruits produced/panicle (A), the number of nuts produced/plant (B), and the production $(\mathrm{kg})$ of nuts/plant $(\mathrm{C})$; the relationship between the area under the severity of powdery mildew in cashew panicles progress curve (AUSevPanPC) and the number of fruits produced/ panicle $(\mathrm{D})$, the number of nuts produced/plant $(\mathrm{E})$, and the production $(\mathrm{kg})$ of nuts/plant $(\mathrm{F})$. Black circles represent the average values observed in each treatment.

Rev. Ceres, Viçosa, v. 66, n.2, p. 132-141, mar/abr, 2019 
res 1,2 , and 3), which was on average 1.2 fruits/panicles and 247.63 nuts/plant; with a productivity of $2.13 \mathrm{~kg}$ of nuts/plant. This productivity corresponds to $447.3 \mathrm{~kg}$ of nut/ha, considering the spacing established in this experiment $(8 \times 6 \mathrm{~m})$, with 210 plants/ha. A small productivity for this clone was observed, since values close to $2000 \mathrm{~kg} /$ ha have already been reported (Paiva \& Barros, 2004), but with plants in different spacing and orchard with age inferior to that analyzed in this assay.

Regarding damages, no relationship between disease and plant production was observed, confirmed by the absence of significance and values of the coefficient of determination close to zero in the linear regressions (Figures 1,2, and 3). These results contrast with those obtained
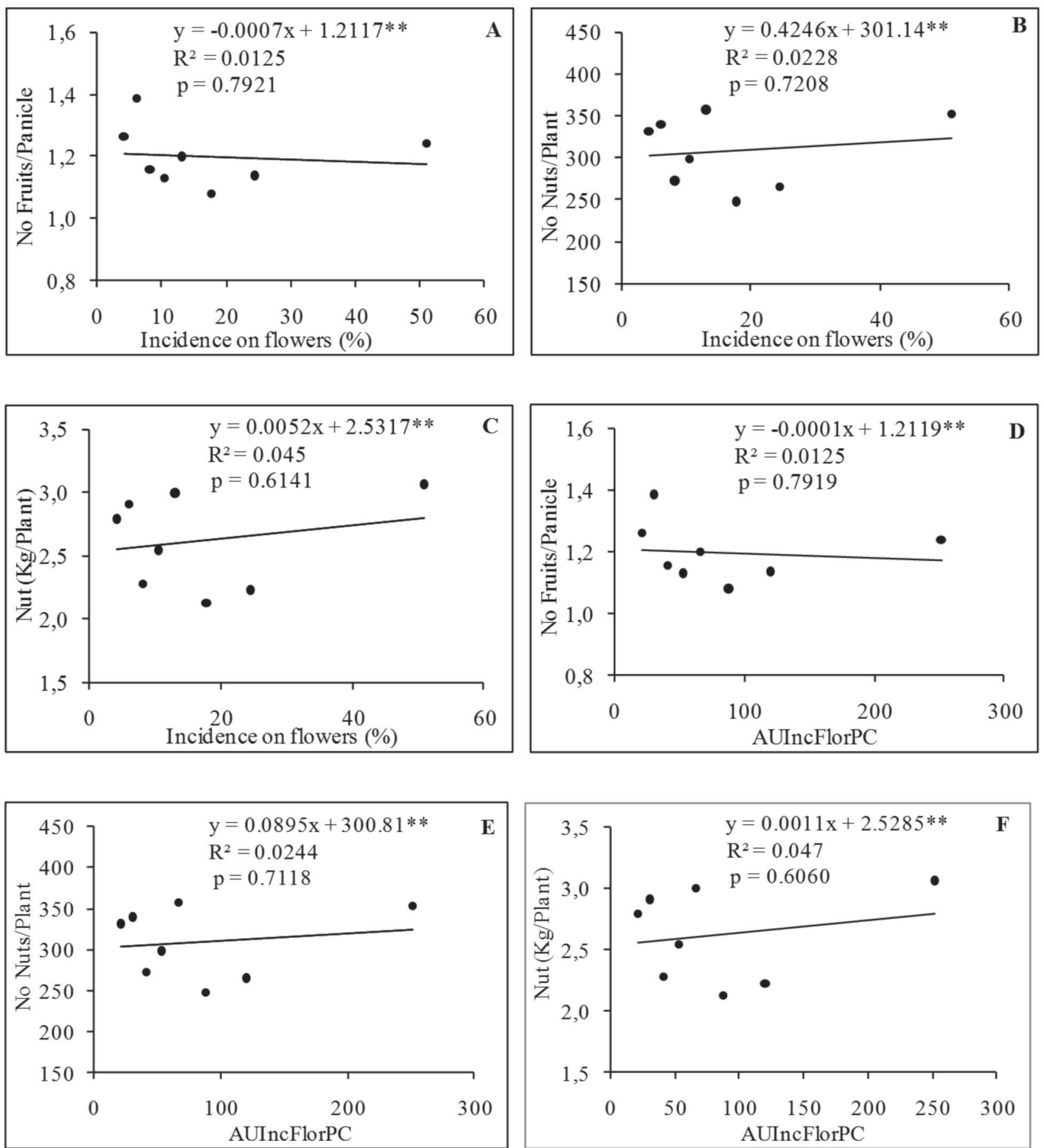

Figure 2: Relationship between the incidence of powdery mildew on flowers (IncFlor) and the number of fruits produced/panicle (A), the number of nuts produced/plant $(\mathrm{B})$, and the production $(\mathrm{Kg})$ of nuts/plant $(\mathrm{C})$; Relationship between the area under the incidence of powdery cashew in flowers progress curve (AUIncFlorPC) and the number of fruits produced/panicle (D), the number of nuts produced/plant (E), and the production $(\mathrm{Kg})$ of nuts/plant $(\mathrm{F})$ of BRS 189 cashew plant. Black circles represent the average values observed in each treatment. 
in African countries with a significant decrease in cashew production, caused by the severe attack of powdery mildew (Casulli, 1979; Martin et al., 1997; Sijaona et al., 2001). In addition, abortion of flowers and fruits was also not observed, which differs from the information reported in other studies on cashew (Cardoso et al., 2012) and recorded in other pathosystems (Camele et al., 2009; Martins et al., 2014). This fact, characterized by the presence of the same number of fruits/panicle in all treatments (Figures 1A, 1D, 2A, 2D, and 3A), shows that powdery mildew in this clone did not cause a decrease in production even at the absence of control and in high intensity of attack on the plant reproductive organs. Despite the severe infection on inflorescences, no symptoms of the disease were observed on the leaves of plants, a common situation in cashew plants grown in other areas under conditions of severe attack of the pathogen, especially on young leaves.

No significant reduction occurred in the mass of the nuts as a function of the attack of powdery mildew on clone BRS189 or in the width of the nut and in the mass of the epicarp and pellicle (Figures 4A, 4C, 4E, and 4F), which presented average values of $8.72 \mathrm{~g}, 28.86 \mathrm{~mm}, 2.18 \mathrm{~g}$, and $0.15 \mathrm{~g}$, respectively.

As shown in the present study, Serrano et al. (2013b) also observed that nuts attacked by powdery mildew in $15 \%$ of the common cashew clones evaluated did not have any reduction in their mass. In this case, there is probably no significant penetration of the fungus that translates any significant damage to the nut. The presence of phenolic components, particularly on the spongy mesophyll of the BRS 189 cashew clone nut, such as anacardic acid, cardanol, and cardol, which, due to their already evidenced action against microorganisms (Mazzetto et al., 2009), could act by preventing the pathogen infection in tissues of the nut, thus avoiding severe damage, even in a condition of high epidemic in the field. On the other hand, because it is considered a pathogen with epiphytic characteristics, it is suggested that the damage is only superficial.

A significant decrease occurred in length and an increase in thickness of kernels due to increase in the disease severity (Figures 4B and 4D), with average values of 33.94 and $20.48 \mathrm{~mm}$, respectively. The variation in the
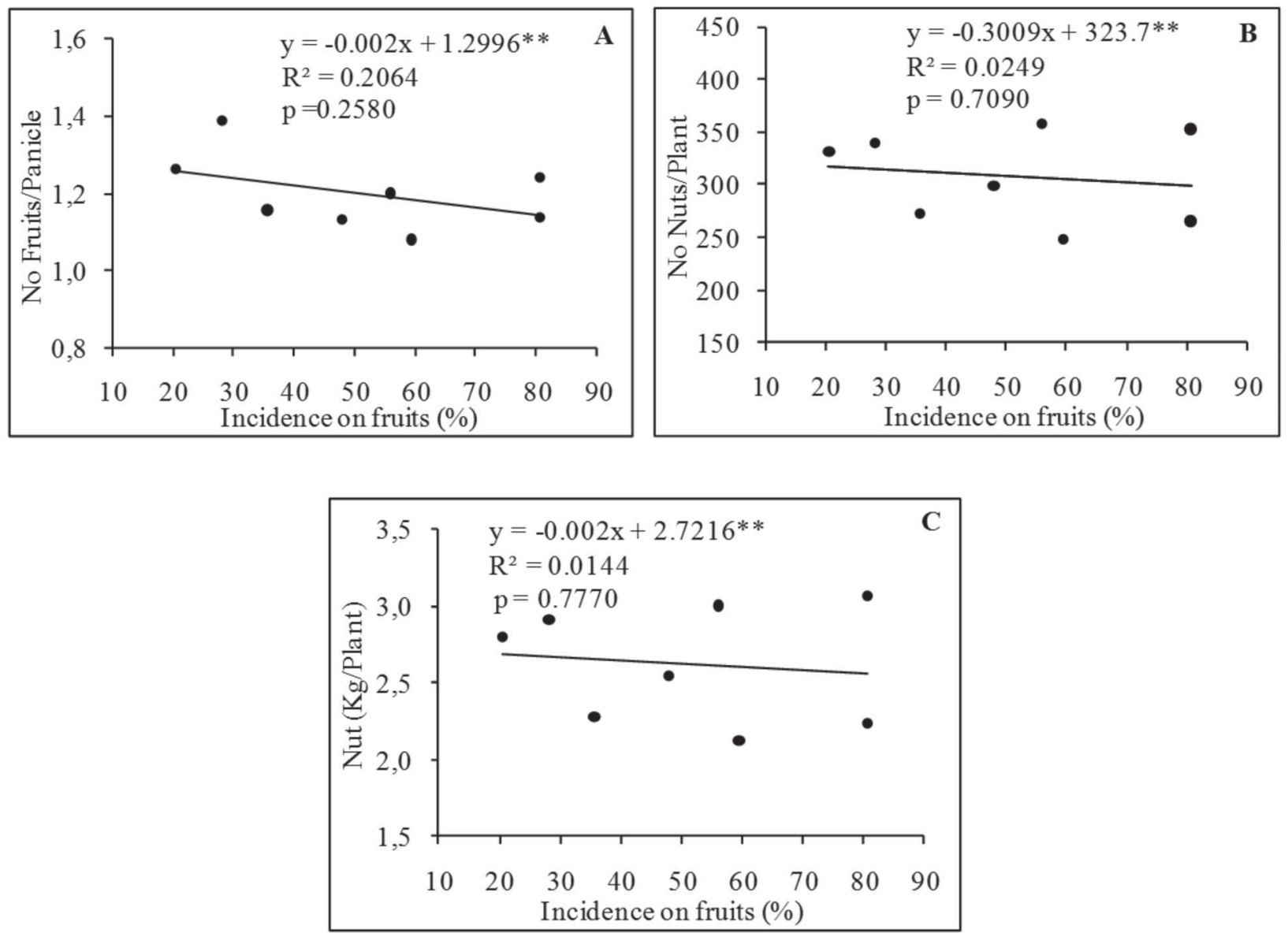

Figure 3: Relationship between the incidence of powdery mildew on fruits (IncFruto) of BRS 189 cashew plant and the number of fruits produced/panicle (A), number of nuts produced/plant (B), and the production $(\mathrm{kg})$ of nuts/plant (C). Black circles represent the average values observed in each treatment. 
length and thickness between the healthy and the most attacked nuts was 2.25 and $3.88 \%$, respectively, which were low values but contributed to cause deformation, reducing by $0.31 \mathrm{~mm}$ the length for each 1 -unit increase in the severity score for powdery mildew on nuts and increase of $0.34 \mathrm{~mm}$ in thickness for each 1-unit increase in the severity score (Figures 4B and 4D).

Other studies have reported the deformation of nuts when attacked by powdery mildew. Serrano et al. (2013b), when studying the effect of powdery mildew on 20 common cashew clones in the state of Piauí, observed that eight out of those materials presented deformations in the nuts when severely attacked by the disease. This fact was also reported by Sijaona (1997) in kernels of several cashew clones cultivated in the African continent.

The BRS 189 cashew clone kernels presented, on average, $2.18 \mathrm{~g}, 25.73 \mathrm{~mm}, 16.02 \mathrm{~mm}$, and $14.17 \mathrm{~mm}$ for mass, length, width, and thickness, respectively. However, unlike
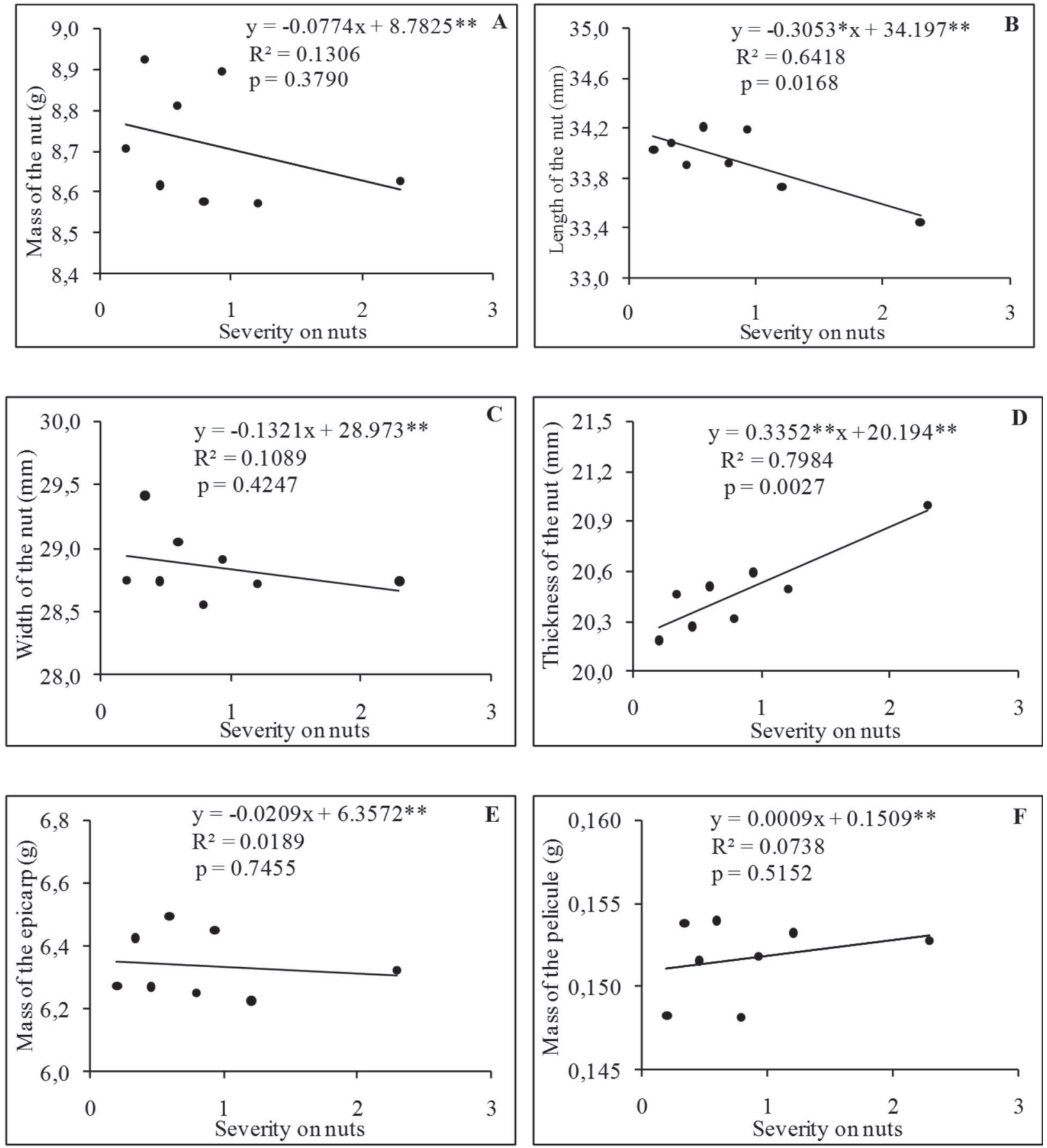

Figure 4: Relationship between the severity of the powdery mildew on nuts (SevCast) and mass (A), length (B), width (C), and thickness of the nut (D), weight of the epicarp (E), and weigh of the pellicle (F). Black circles represent the average values observed in each treatment. 
the nuts analyzed in this study, all the biometric characteristics of the kernels were affected by powdery mildew (Figures 5A-D), corroborating results obtained by Serrano et al. (2013b). The kernels from the treatment affected by the greatest severity of nuts showed a reduction of $4.74,4.34$, and $5.05 \%$ in the mass, length, and width, respectively, when compared with those in the less affected treatments. Similar to what occurred with the nuts, there was also an increase in thickness of the kernels, causing deformation (Figure 5D).

The largest growth rate of kernels occurs in the final stage of formation of the cashew fruit, unlike the epicarp, which is formed early in fruit development. During this period, the infected peduncle in plants infected by powdery mildew may hinder the translocation of the necessary compounds to the complete kernel formation, compromising its quality.

The damage caused by cashew powdery mildew does not directly affect the BRS 189 clone nut, but the kernels have their quantitative characteristics affected. In the processing of severely infected nuts, the yield decreased by almost $5 \%$, causing a reduction of $0.04 \mathrm{~g}$ in the mass of each kernel for each 1-unit increase in the powdery mildew score observed in the nuts (Figure 5A). This corresponds to a decrease of $18.35 \mathrm{~g}$ in each $\mathrm{kg}$ of processed kernel. Considering the length and thickness of the kernel, it is likely that the observed damage (Figures 5B and 5D) follows that observed in the nuts (Figures 4B and 4D).

Mass, size (width and thickness), and total soluble solids (TSS) of BRS 189 clone peduncles were severely influenced by powdery mildew, as verified by analyses of highly significant linear regressions (Figure 6). The peduncle presented values of $114.31 \mathrm{~g}, 52.99 \mathrm{~mm}, 59.26$ $\mathrm{mm}$, and $13.63^{\circ}$ Brix, for mass, length, width, and TSS, on average, respectively. However, while the peduncles of the plants less attacked by the disease had a mass of $135.74 \mathrm{~g}$, length of $58.56 \mathrm{~mm}$, width of $63.44 \mathrm{~mm}$, and TSS of $12.76^{\circ} \mathrm{Brix}$, the most affected plants produced peduncles with $68.76 \mathrm{~g}, 41.49 \mathrm{~mm}, 48.49 \mathrm{~mm}$, and 16.34 ${ }^{\circ}$ Brix, meaning an average reduction of $49.35,29.15$, and $23.56 \%$ in mass, length, and width of the peduncle, and an increase of $21.86 \%$ in TSS, respectively. The affected peduncles, besides the reduced size and mass, also presented wrinkling, variegation, and cracks on their surface, resulting from the necrosis of the surface cells caused by fungus infection.
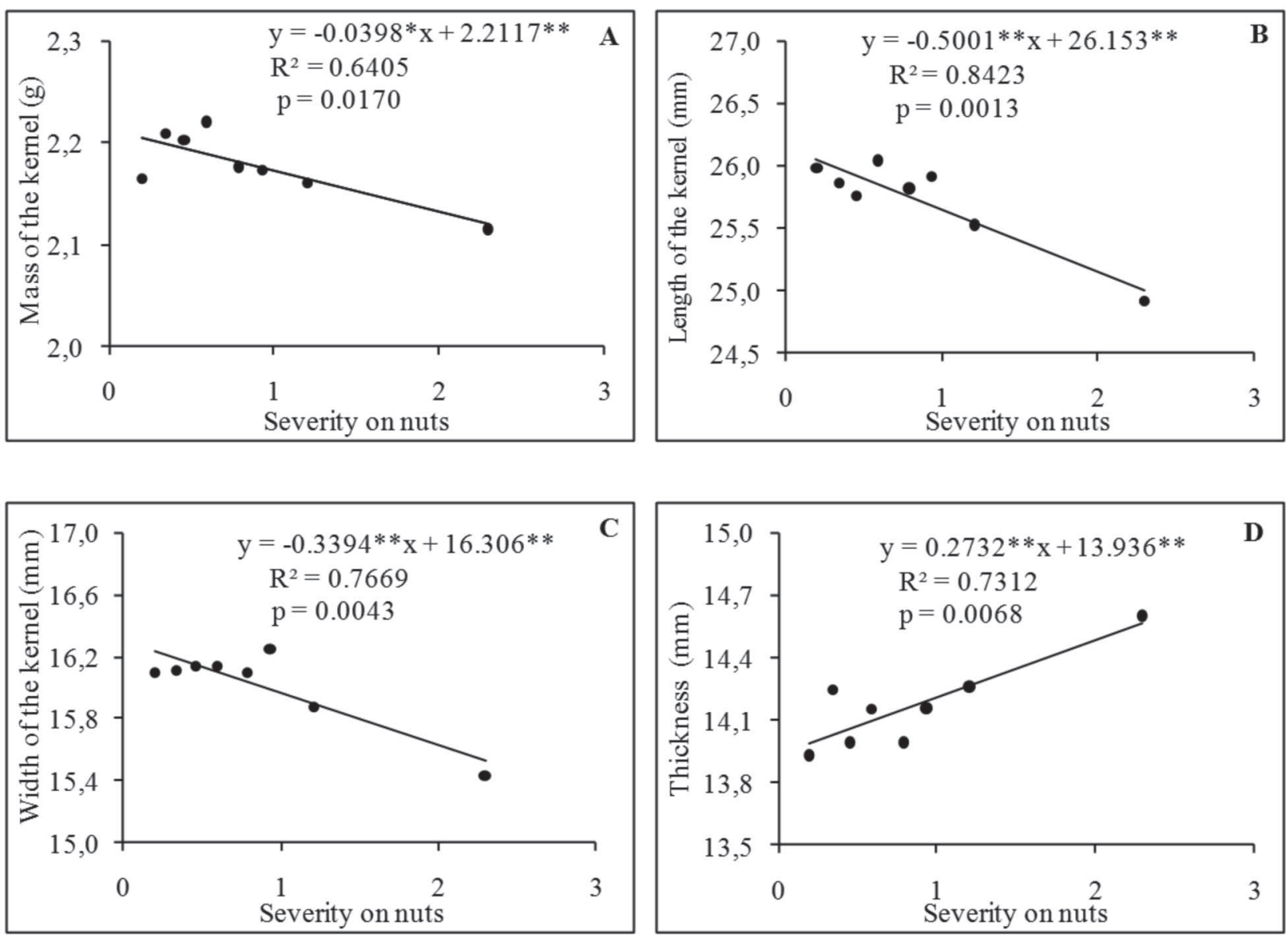

Figure 5: Relationship between the severity of the powdery mildew on nuts (SevPseud) and mass (A), length (B), width (C), and thickness of the kernel (D) of the BRS 189 cashew plant. Black circles represent the average values observed in each treatment. 
The percentage reduction of almost $50 \%$ in the mass of the peduncle as a result of the attack of powdery mildew is considered very significant, with significant damage to the production of the plant. In other pathosystems, different species of powdery mildew have caused significant damage to a greater or lesser extent. Watson (2016) reported that Erysiphe heraclei infection on carrot plants ("Ricardo" cultivar) reduced their weight by $80 \%$. Santos et al. (2005) found a reduction in melon fruit mass affected by Sphaerotheca fuliginea; however, these values did not exceed $13.3 \%$. Bowen et al. (1991) reported production losses by $14.5 \%$ in wheat plants, while Reis et al. (2002) reported a $28.03 \%$ reduction in barley yield, both of which were affected by Blumeria graminis. Godoy \& Canteri (2004) also verified a reduction of $17 \%$ in the production of soybean attacked by Erysiphe diffusa.

The peduncles of the severely attacked cashews can be sent to the industry of juices due to a greater amount of sugars. However, the yield in volume should be hampered by the significant reduction that the powdery mildew causes in this organ. The increased TSS in fruits infected by powdery mildew did not correspond to the effect of Sphaerotheca fuliginea on melon fruit (Santos et al., 2005).

In the linear regressions obtained for the characteristics of the peduncle (Figure 6), each 1-unit increase in the severity score of the powdery mildew reduced the mass, length, and width of the peduncle by $18.73 \mathrm{~g}, 4.72 \mathrm{~mm}$, and $4.41 \mathrm{~mm}$, respectively. Considering a density of 210 plants/ ha of clone BRS 189, under conditions of high incidence of powdery mildew, there will be a reduction in peduncle productivity of $1,212.66 \mathrm{~kg} / \mathrm{ha}$ for each 1-unit increase in the severity score, drastically reducing profitability of the producer and increasing the losses when this clone is grown to produce cashew for the market of fresh fruits. The damages are not only reflected in the productivity of stalks but, mainly, in the depreciation due to its dry appearance, cracked and unfit for trade. In this case, the damages can reach $100 \%$ in conditions of high severity of the disease and in the absence of control.

The most significant damages that occurred on the peduncles were mainly due to the reaction of the initial infection of these organs. Due to their constant exposure
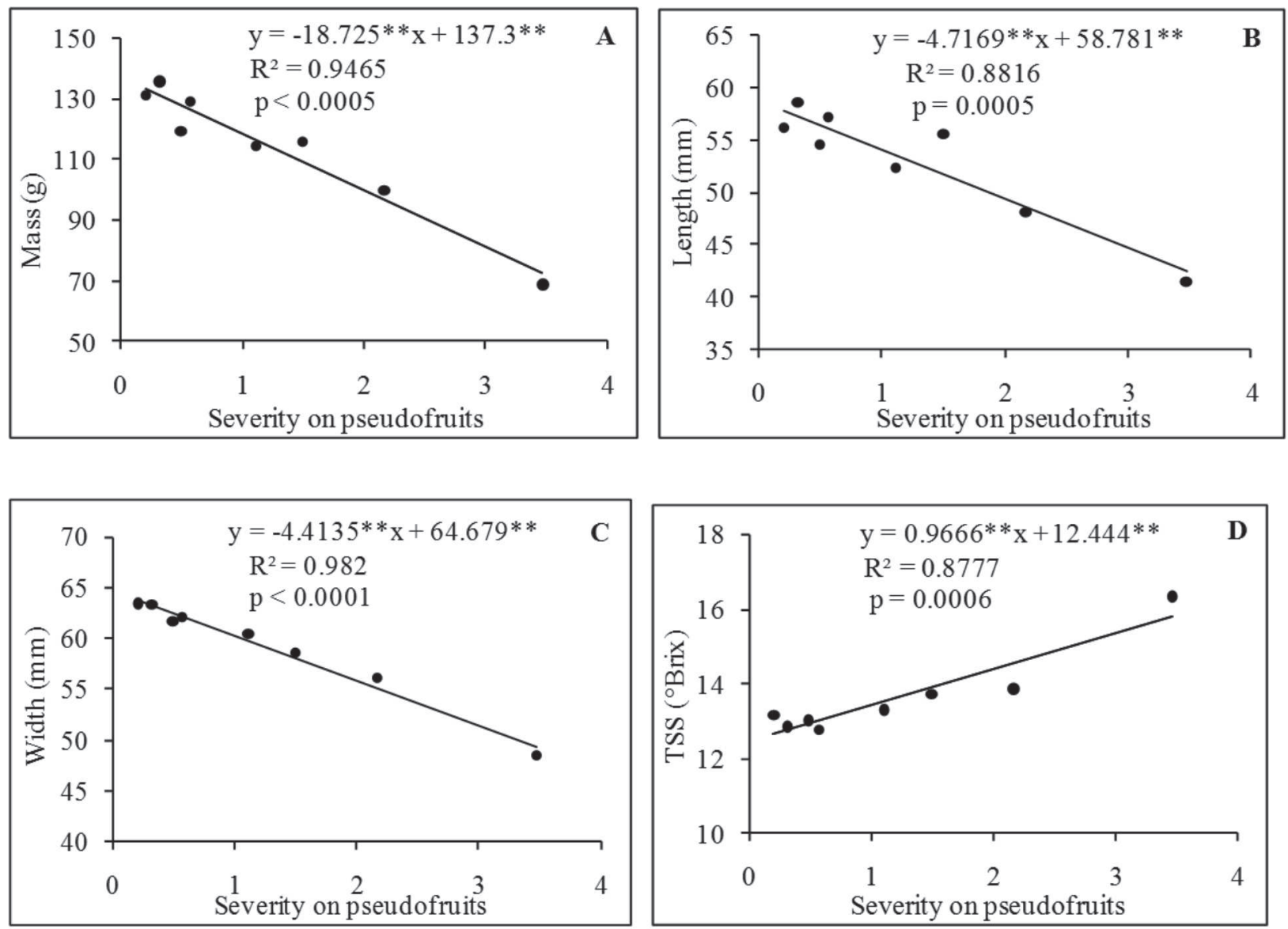

Figure 6: Relationship between the severity of the powdery mildew on pseudofruit (SevPseud) of the BRS 189 cashew plant and its mass (A), length (B), width (C), and total soluble solids (TSS) (D). Black circles represent the average values observed in each treatment. 
since the emission of flowers, the peduncles are subject to the attack of powdery mildew for a longer time, while the nuts remain protected until the petals and sepals of the flowers fall. This explains the likely difference in the degree of pathogen attack in these organs and in damages occurred in BRS 189 cashew.

Under the conditions studied, clone BRS 189 was tolerant to cashew powdery mildew in relation to cashew production in number and mass. For the other variables referring to kernels and peduncles, the behavior of the clone was different. However, the most significant damage was in the production of peduncle, whereas for nuts, new approaches with this clone deserve to be verified, especially in other producing regions where the presence of leaf infections can also alter the damage relationships caused by the disease. For the same clone and under the same conditions, Martins et al. (2017) reported that powdery mildew did not interfere in the mass of the nuts and in number of maturis, even at marked levels of disease.

\section{CONCLUSIONS}

Powdery mildew does not cause fruit drop neither reduces the productivity of nuts in the BRS 189 dwarf cashew clone.

The occurrence of powdery mildew reduces mass and size of the kernel and peduncle of BRS 189 cashew clone.

The powdery mildew impairs the production of cashew peduncle for fresh fruit market in BRS 189 clone.

\section{REFERENCES}

Barros BC, Castro JL \& Patrício FRA (2006) Resposta de cultivares de trigo (Triticum aestivum L.) ao controle químico das principais doenças fúngicas da cultura. Summa Phytopathologica, 32:239-246.

Bowen KL, Everts KL \& Leath S (1991) Reduction in yield of winter wheat in North Carolina due powdery mildew and leaf rust. Phytopathology, 81:503-511.

Braun U \& Cook RTA (2012) Taxonomic Manual of the Erysiphales (Powdery Mildews). Saint Paul, American Phytopathological Society. 707p.

Camele I, Campanelli G, Ferrari V, Viggiani G \& Candido V (2009) Powdery mildew control and yield response of Inodorus melon. Italian Journal Agronomic, 02:19-26.

Campbell CL \& Madden LV (1990) Introduction to plant disease epidemiology. New York, Wiley-Interscience. 532p.

Cardoso JE, Martins MVV, Lima JS, Viana FMP \& Silva LGC (2012) Controle químico do oídio do cajueiro. Fortaleza, Embrapa Agroindústria Tropical. 4p. (Comunicado Técnico, 196).

Cardoso JE, Viana FMP, Freire FCO \& Martins MVV (2013) Doenças do cajueiro. In: Araújo JPP (Ed) Agronegócio caju: práticas e inovações. Brasília, Embrapa Informação Tecnológica. p. 217-238.

Casulli F (1979) II mal bianco dell'anacardio in Tanzania. Rivista di Agricoliura Subtropicale e Tropicale, 13:241-248.
Cavalcanti JJV, Cardoso JE, Barros LM \& Felipe EM (2000) Resistência genética de clone de cajueiro anão precoce às principais fitomoléstias. Fortaleza, Embrapa Agroindústria Tropical. 15p. (Boletim de Pesquisa, 34).

Costa CAR, Aguiar MJN \& Lima JB (1999) Uso de sistema de informações geográficas no mapeamento da produção, produtividade e área plantada de cajueiro na região Nordeste. Fortaleza, Embrapa Agroindústria Tropical. 18p. (Boletim de Pesquisa, 26).

Freire FCO, Cardoso JE, Santos AA \& Viana FMP (2002) Diseases of cashew nut plants (Anacardium occidentale L.) in Brazil. Crop Protection, 21:489-494.

Godoy CV \& Canteri MG (2004) Efeito da severidade de oídio e crestamento foliar de cercospora na produtividade da cultura da soja. Fitopatologia Brasileira, 29:526-531.

Igarashi S, Oliveira GM, Camargo LCM, Falkoski Filho J, Gardiano CG \& Balan MG (2010) Danos causados pela infecção de oídio em diferentes estádios fenológicos da soja. Arquivos do Instituto Biológico, 77:245-250.

Martins MVV, Lima JS, Viana FMP, Cardoso JE, Araújo FSA \& Ootani MA (2017) Influência das épocas de floração e dos períodos de proteção fenológica à infecção do oídio no clone de cajueiro-anão BRS 189. Revista Ceres, 64:574-581.

Martins MVV, Silveira SF \& Maffia LA (2014) Guava fruit loss caused by rust. Summa Phytopathologica, 40:107-113.

Martin PJ, Topper CP, Bashiru RA, Boma F, Waal D, Harries HC, Kasuga LJ, Katanila N, Kikoka LP, Lamboll R, Maddison AC, Majule AE, Masawe PA, Millanzi KJ, Nathaniels NQ, Mazzetto SE, Lomonaco D \& Mele G (2009) Óleo da castanha de caju: oportunidades e desafios no contexto do desenvolvimento e sustentabilidade industrial. Química Nova, 32:732-741.

Oliveira VH, Barros LM \& Lima RN (2003) Influência da irrigação e do genótipo na produção de castanha em cajueiro-anão precoce. Pesquisa Agropecuária Brasileira, 38:61-66.

Oliveira VH (2002) Cultivo do cajueiro anão precoce. Fortaleza, Embrapa Agroindústria Tropical. 40p. (Sistema de Produção, 01).

Paiva JR \& Barros LM (2004) Clone de cajueiro: obtenção, características e perspectivas. Fortaleza, Embrapa Agroindústria Tropical. 26p. (Documentos, 82).

Pinto ORO, Muniz CR, Cardoso JE, Oliveira FSA \& Lima JS (2016) Morphological analyses of Pseudoidium anacardii infecting brazilian cashew plants. Summa Phytopathologica, 42:257-260.

Reis EM, Hoffmann LL \& Blum MMC (2002) Modelo de ponto crítico para estimar os danos causados pelo oídio em cevada. Fitopatologia Brasileira, 27:644-646.

Santos AA, Viana FMP, Cardoso JE \& Vidal JC (2005) Efeito do oídio na produção e no teor de sólidos solúveis totais de frutos do meloeiro. Revista Ciência Agronômica, 36:354-357.

Serrano LA, Melo DS, Taniguchi CAK, Vidal Neto FC \& Cavalcante Júnior LF (2013a) Porta enxertos para a produção de mudas de cajueiro. Pesquisa Agropecuária Brasileira, 48:1237-1245.

Serrano LA, Vidal Neto FC, Melo DS \& Cardoso, JE (2013b) Influência do oídio nas castanhas de diferentes genótipos de cajueiro. Fortaleza, Embrapa Agroindústria Tropical. 20p. (Boletim de Pesquisa e Desenvolvimento, 76).

Shomari SH \& Kennedy R (1999) Survival of Oidium anacardii on cashew (Anacardium occidentale) in southern Tanzania. Plant Pathology, 48:505-513.

Shomari SH \& Kennedy R (1997) Field and laboratory investigations on the development of Oidium anacardii in relation to environmental factors. In: International Cashew \& Coconut Conference, Dar es Salaam. Anais, BioHybrids International Ltd. p.260-265.

Rev. Ceres, Viçosa, v. 66, n.2, p. 132-141, mar/abr, 2019 
Sijaona MER, Clewerb A, Maddisonc A \& Mansfielda JW (2001) Comparative analysis of powdery mildew development on leaves, seedlings and flower panicles of different genotypes of cashew. Plant Pathology, 50:234-243.

Sijaona MER \& Mansfield JW (2001) Variation in the response of cashew genotypes to the targeted application of fungicide to flower panicles for control of powdery mildew disease. Plant Pathology, 50:244-248.

Sijaona MER \& Mansfield JW (1997) Studies on cashew resistance to powdery mildew (Oidium anacardii Noack). In: International Cashew \& Coconut Conference, Dar es Salaam. Anais, BioHybrids International Ltd. p.266-269.

Sijaona MER (1997) Studies on aspects of cashew resistance to powdery mildew (Oidium anacardii Noack). Tese de Doutorado. University of London, London. 316p.

Smith DN \& Cooper JF (1997) Control of powdery mildew on cashew in Tanzania using sulphur dust - an audit of sulphur fate and a proposal for a new dusting strategy. Crop Protection, 16:49-552.

Smith DN, King WJ, Topper CP, Borna F \& Cooper JF (1995) Alternative techniques for the application of sulphur dust to cashew trees for the control of powdery mildew caused by the fungus Oidium anacardii in Tanzania. Crop Protection, 14:555560 .
Smith DN, King WJ, Topper CP, Mhando H \& Cooper JF (1997) Studies on spray deposition on cashew trees in Tanzania with reference to the use of fungicides to control Oidium anacardii. Crop Protection, 16:313-322.

Souza MF, Miranda OC, Paiva JR, Barros LM, Correa MCM, Cavalcanti JJV \& Melo DS (2004) BRS 253 ou BRS BAHIA 12: clone de cajueiro-anão precoce para plantio comercial no $\mathrm{Mu}-$ nicípio de Ribeira do Pombal-BA, e áreas similares. Fortaleza, Embrapa Agroindústria Tropical. 26 p. (Boletim de Pesquisa e Desenvolvimento, 17).

Topper CP, Boma F \& Mhando H (1997a) Evaluation of fungicides for the control of powdery mildew (Oidium anacardii Noack) on cashew in Tanzania. In: Fungicide strategy development trials. International Cashew \& Coconut Conference, Dar es Salaam. Anais, BioHybrids International Ltd. 254-259.

Topper CP, Boma F \& Mhando H (1997b) Evaluation of fungicides for the control of powdery mildew (Oidium anacardii Noack) on cashew in Tanzania. In: On-farm testing of fungicide control strategies. International Cashew \& Coconut Conference, Dar es Salaam. Anais, BioHybrids International Ltd. 270-276.

Wang L, Wang M \& Zhang Y (2014) Effects of powdery mildew infection on chloroplast and mitochondrial functions in rubber tree. Tropical Plant Pathology, 39:242-250.

Watson A (2016) Managing carrot powdery mildew. Australasian Plant Pathology, 45:29-35. 